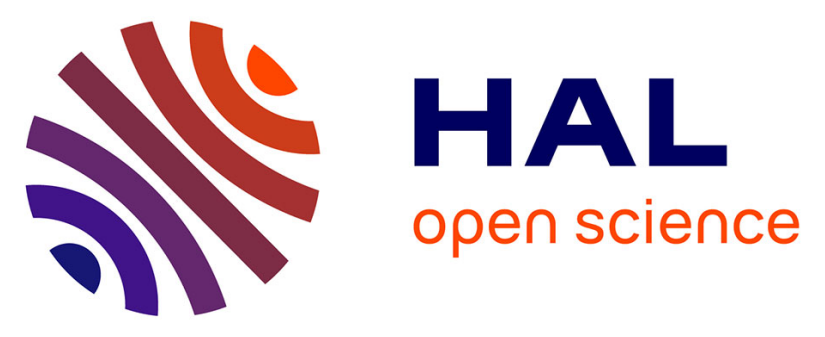

\title{
Chemo-enzymatic synthesis of (2S,4R)-2-amino-4-(3-(2,2-diphenylethylamino)-3 oxopropyl)pentanedioic acid: A novel Selective inhibitor of human excitatory amino acid transporter subtype 2
}

Emmanuelle Sagot, Anders A. Jensen, Darryl S. Pickering, Xiasui Pu, Michelle Umberti, Tine B. Stensbol, Brigitte Nielsen, Zeinab Assaf, Bettina Aboab, Jean Bolte, et al.

\section{- To cite this version:}

Emmanuelle Sagot, Anders A. Jensen, Darryl S. Pickering, Xiasui Pu, Michelle Umberti, et al.. Chemo-enzymatic synthesis of (2S,4R)-2-amino-4-(3-(2,2-diphenylethylamino)-3 oxopropyl)pentanedioic acid: A novel Selective inhibitor of human excitatory amino acid transporter subtype 2. Journal of Medicinal Chemistry, 2008, 51, pp.4085-4092. hal-00323786

\author{
HAL Id: hal-00323786 \\ https://hal.science/hal-00323786
}

Submitted on 23 Sep 2008

HAL is a multi-disciplinary open access archive for the deposit and dissemination of scientific research documents, whether they are published or not. The documents may come from teaching and research institutions in France or abroad, or from public or private research centers.
L'archive ouverte pluridisciplinaire $\mathbf{H A L}$, est destinée au dépôt et à la diffusion de documents scientifiques de niveau recherche, publiés ou non, émanant des établissements d'enseignement et de recherche français ou étrangers, des laboratoires publics ou privés. 


\title{
Chemo-Enzymatic Synthesis of (2S,4R)-2-Amino-4-(3-(2,2-diphenylethylamino)-3- oxopropyl)pentanedioic Acid: A Novel Selective Inhibitor of Human Excitatory Amino Acid Transporter Subtype 2
}

\author{
Emanuelle Sagot, ${ }^{\ddagger}$ Anders A. Jensen, ${ }^{\dagger}$ Darryl S. Pickering, ${ }^{8}$ Xiaosui Pu, ${ }^{\prime \prime}$ Michelle Umberti," Tine B. Stensbøl, ${ }^{\perp}$ \\ Birgitte Nielsen, ${ }^{\ddagger}$ Zeinab Assaf, ${ }^{\ddagger}$ Bétina Aboab, ${ }^{\ddagger}$ Jean Bolte, ${ }^{\ddagger}$ Thierry Gefflaut, ${ }^{* \neq}$ and Lennart Bunch* ${ }^{*}+\ddagger$ \\ Department of Medicinal Chemistry, The Faculty of Pharmaceutical Sciences, University of Copenhagen, Universitetsparken 2, DK-2100 \\ Copenhagen, Denmark, Département de Chimie, Université Blaise Pascal, 63177 Aubière Cedex, France, Department of Pharmacology and \\ Pharmacotherapy, The Faculty of Pharmaceutical Sciences, University of Copenhagen, Universitetsparken 2, DK-2100 Copenhagen, Denmark, \\ Biological Research, H. Lundbeck A/S, 215 College Road, Paramus, New Jersey 07652, Department of Neurobiology, H. Lundbeck A/S, \\ Ottiliavej 9, DK-2500 Valby, Denmark
}

\begin{abstract}
In the mammalian central nervous system (CNS), the action of sodium dependent excitatory amino acid transporters (EAATs) is responsible for termination of glutamatergic neurotransmission by reuptake of $(S)$ glutamate (Glu) from the synaptic cleft. Five EAAT subtypes have been identified, of which EAAT1-4 are present in the CNS, while EAAT5 is localized exclusively in the retina. In this study, we have used an enantioselective chemo-enzymatic strategy to synthesize 10 new Glu analogues $\mathbf{2 a}-\mathbf{k}$ (2d is exempt) with different functionalities in the $4 R$-position and characterized their pharmacological properties at the human EAAT1-3. In particular, one compound, $\mathbf{2 k}$, displayed a significant preference as inhibitor of the EAAT2 subtype over EAAT1,3. The compound also displayed very low affinities toward ionotropic and metabotropic Glu receptors, making it the most selective EAAT2 inhibitor described so far.
\end{abstract}

\section{Introduction}

In the mammalian central nervous system (CNS) glutamatergic neurotransmission is terminated by reuptake of (S)-glutamate (Glu) from the synaptic cleft by the action of a family of sodium dependent excitatory amino acid transporters (EAATs). ${ }^{1,2}$ To date, five transporter subtypes have been identified, of which four, EAAT1-4, are present in the mammalian CNS while EAAT5 is localized exclusively in the retina. ${ }^{a}$ EAAT1-3 are localized on neurons and/or in astroglial cells and exhibit high capacity for transporting Glu across the membrane, whereas EAAT4 and EAAT5 predominately function as Glu-gated chloride channels. ${ }^{1}$ In the healthy CNS, activation of Glu receptors is involved in important neurophysiological processes underlying memory and learning, motor functions, and neural plasticity and development. ${ }^{3}$ However, under conditions of metabolic stress and oxygen deprivation, Glu is a neurotoxic agent. Thus, it is believed that neurodegenerative diseases such as Alzheimer's disease, dementia, Huntington's disease, amyotrophic lateral sclerosis, epilepsy, and cerebral stroke may be related to disordered glutamatergic neurotransmission originating from dysfunction of either the ionotropic Glu receptors (iGluR),

* To whom correspondence should be addressed. For L.B. Phone, +45 35336244; fax, +45 35336040; e-mail, lebu@farma.ku.dk. For T.G. (for correspondence regarding the synthetic work): Phone, +33 473407866, fax, +33 473407717; e-mail, thierry.gefflaut@univ-bpclermont.fr.

${ }^{\dagger}$ Department of Medicinal Chemistry, The Faculty of Pharmaceutical Sciences, University of Copenhagen.

${ }^{\ddagger}$ Département de Chimie, Université Blaise Pascal.

${ }^{8}$ Department of Pharmacology and Pharmacotherapy, The Faculty of Pharmaceutical Sciences, University of Copenhagen.

"Biological Research, H. Lundbeck A/S.

${ }^{\perp}$ Department of Neurobiology, H. Lundbeck A/S.

${ }^{a}$ Abbreviations: iGluR, ionotropic Glu receptors; mGluR, metabotropic Glu receptors; EAAT, excitatory amino acid transporter; $\mathrm{KG}, \alpha$-ketoglutarates; AAT, aspartate aminotransferase; DHK, dihydrokainic acid; TBOA, threo-benzyloxyaspartate; AMPA, 2-amino-3-(3-hydroxy-5-methyl-4-isoxazolyl)propionic acid; KA, kainic acid; NMDA, $N$-methyl-D-aspartic acid; FMP, FLIPR membrane potential. the metabotropic Glu receptors (mGluR), or the Glu reuptake system (EAATs). ${ }^{3,4}$

In several recent studies, we have explored the structure-activity relationship (SAR) of ligands targeting human EAATs, with the ultimate goal of identifying new EAAT subtype selective inhibitors and substrates. ${ }^{5-8}$ In this paper, we present the pharmacological evaluation of Glu analogues $2 \mathbf{2 a}-\mathbf{k}$ ( $\mathbf{2 b}$ is exempt) at human EAAT1-3 and the chemo-enzymatic synthetic strategy developed for the preparation of amide analogues $2 \mathbf{g}-\mathbf{k}$. Furthermore, a modeling study addressing the observed structure-activity relations is presented.

\section{Chemistry}

The enzyme aspartate aminotransferase (AAT), isolated from E. coli, may catalyze the stereoselective conversion of substituted $\alpha$-ketoglutarates $(\mathrm{KG})$ into their corresponding L-Glu analogues. Using this approach, we have previously prepared a series of L-2,4-syn-4-alkyl Glu analogues starting from their corresponding racemic $\mathrm{KGs},{ }^{6}$ thus demonstrating the $\mathrm{KG}$ substrate tolerance and that AAT is highly enantioselective. In this paper, we show that this methodology can be extended to also cover a range of functionalized side chains in the 4-position of KG (Scheme 1).

Whereas the enantioselective preparation of Glu analogues $\mathbf{2 a}-\mathbf{f}$, including their corresponding $\mathrm{KG}$ precursors, is reported elsewhere by us, ${ }^{9}$ the synthesis of 4-amide functionalized KGs $\mathbf{1} \mathbf{g}-\mathbf{k}$ is based on an original approach starting from the cyclohexanone 3 (Scheme 2). The well-known disubstituted cyclohexanone 3 was readily prepared from methyl malonate and methyl acrylate following a described four-step procedure involving a double Michael condensation and a Dieckmann reaction. ${ }^{10}$ This cyclic $\beta$-keto ester was then converted in high yield to the enamines $\mathbf{4 g}-\mathbf{k}$ by treatment with ammonia or several primary amines. Oxidative cleavage by ozone of the various enamines $\mathbf{4 g}-\mathbf{k}$ afforded simultaneously the $\alpha$-keto ester 
Scheme 1. AAT Catalyzed Synthesis of 4-Substituted Glu Analogues $2 \mathbf{a}-\mathbf{k}$

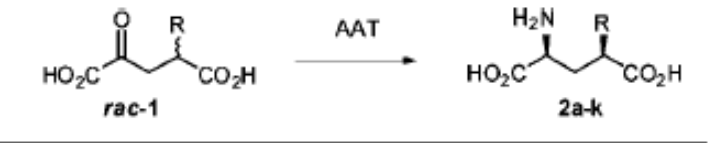

$$
\begin{aligned}
& \text { R R } \\
& \text { a }
\end{aligned}
$$

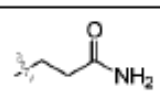

$$
\begin{aligned}
& \text { e 敞 } \\
& \text { h } \text { ل }_{\mathrm{NHMe}} \\
& \text { i } \mathrm{l}_{\mathrm{H}} \\
& \text { j } \mathrm{l}_{\mathrm{H}}^{\mathrm{N}} \widehat{\mathrm{Pn}}_{\mathrm{Pn}} \\
& \text { f } \mathrm{H}_{\mathrm{OH}} \\
& k \overbrace{\mathrm{H}}^{\mathrm{O}} \overbrace{\mathrm{Ph}}^{\mathrm{Ph}}
\end{aligned}
$$

Scheme 2. Synthesis of 4-Amide Functionalized KGs $1 \mathrm{~g}-\mathrm{k}$

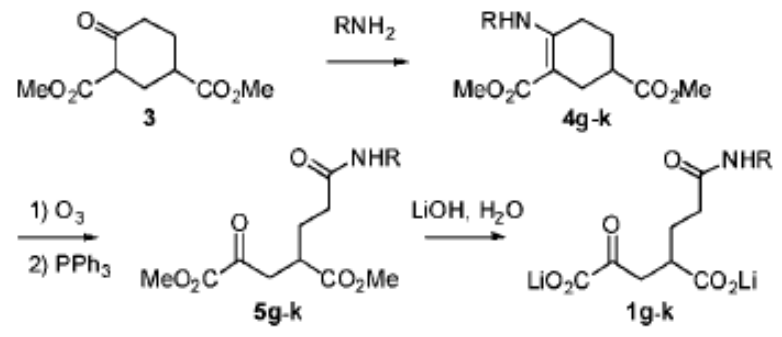

Scheme 3. Oxidation of Enamines $4 \mathrm{~g}-\mathbf{k}$

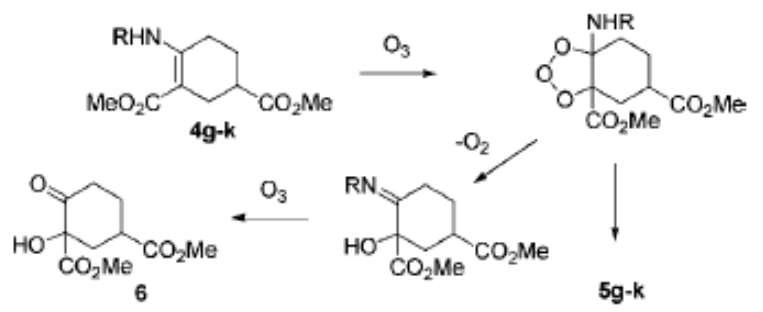

moiety and the amide functionality. The ketoglutarates $\mathbf{5} \mathbf{g}-\mathbf{k}$ were thus isolated with overall yields of $25-55 \%$ from 3 . This modest yield resulted from a competitive oxidation reaction, giving, in every case, the 2-hydroxy cyclohexanone 6, presumably via an elimination of $\mathrm{O}_{2}$ from the primary ozonides formed from $\mathbf{4 g}-\mathbf{k}$ (Scheme 3). Despite this side reaction, the procedure described in Scheme 2 offers an easy and short route to a variety of amide-substituted KGs. Ester hydrolysis was finally done with a stoichiometric amount of $\mathrm{LiOH}$ and gave the desired KGs $\mathbf{1 g}-\mathbf{k}$ in quantitative yields.

The substituted KGs were evaluated as substrate for E. coli AAT on the basis of the Michaelis-Menten model. Table 1 summarizes the kinetic constants measured for the transamination reaction of $\mathbf{1 g}-\mathbf{k}$ in the presence of aspartic acid used as the amino donor in quasisaturating concentration $(40 \mathrm{mM})$.

The $K_{\mathrm{m}}$ values measured with $\mathbf{1 g}-\mathbf{k}$ are in the mmol range,

\begin{tabular}{|c|c|c|c|}
\hline Substrate & $\mathbf{R}$ & $\begin{array}{c}\mathbf{K}_{\mathrm{m}} \\
(\mathbf{m} \mathbf{M})\end{array}$ & $\begin{array}{c}\mathbf{k}_{\text {cat }} \\
\text { rel.(\%) }\end{array}$ \\
\hline KG & - & $0.23 \pm 0.05$ & $100^{b} \pm 3$ \\
\hline $1 \mathrm{~g}$ & & $4.2 \pm 0.3$ & $24.6 \pm 3.2$ \\
\hline $1 \mathrm{~h}$ & & $4.6 \pm 1.2$ & $10.3 \pm 1.7$ \\
\hline $1 \mathrm{i}$ & & $14.5 \pm 0.8$ & $7.6 \pm 0.6$ \\
\hline $1 \mathrm{j}$ & & $2.9 \pm 0.5$ & $15.0 \pm 2.2$ \\
\hline $1 k$ & & $2.3 \pm 0.1$ & $10.7 \pm 1.2$ \\
\hline
\end{tabular}
1 to 2 orders of magnitude higher than that of the natural substrate (KG). This result contrasts with the observations made previously with the 4-alkyl derivatives, which showed very good affinities for the enzyme active site. ${ }^{6}$ More interestingly,
Table 1. Kinetic Parameters of AAT Catalyzed Transaminations of KG Analogues $1 \mathrm{~g}-\mathbf{k}^{a}$

${ }^{a}$ Values and standard errors were calculated from the Hanes-Woolf plot according to the least-squares method and Gauss's error propagation law. ${ }^{b}$ The absolute $k_{\text {cat }}$ value measured in our experimental conditions was $39.6 \pm 1.2 \mathrm{~s}^{-1}$.

however, the $k_{\text {cat }}$ measured with $1 \mathbf{g}-\mathbf{k}$ are all close to $10 \%$ of that of KG thus offering the opportunity of synthetic applications. Preparative scale transaminations were carried out as previously described, by an equilibrium shifted reaction using cysteine sulfinic acid (CSA) as the amino donor substrate: during the reaction, CSA is converted into the very unstable pyruvyl sulfinic acid that decomposes into sulfur dioxide and pyruvic acid, which is not a substrate for AAT. The transamination reaction was monitored by enzymatic titration of pyruvic acid using lactate dehydrogenase and NADH. When a conversion rate around $40 \%$ was reached, the reaction was stopped to achieve the kinetic resolution of the keto acid substrates. Glu analogues were selectively adsorbed on a short column of sulfonic resin $\left(\mathrm{H}^{+}\right.$form) and then eluted with aqueous ammonia. Finally, ion exchange chromatography on cationic dowex 1 resin $\left(\mathrm{AcO}^{-}\right.$form) afforded $\mathbf{2} \mathbf{g}-\mathbf{k}$, each compound being isolated as a single stereomer in $35-46 \%$ yield. AAT was previously shown to display a very high stereoselectivity in favor of the L-2,4syn-4-alkyl Glu derivatives. ${ }^{6,11}$ The L-2,4-syn configuration was thus expected for the new Glu analogues $2 \mathbf{g}-\mathbf{k}$. The configuration was demonstrated, as an example, in the case of the amide $2 \mathbf{k}$ : an aqueous solution of this compound was heated to form a lactame which was then converted into the ester 7 in the presence of methanol and thionyl chloride. NMR analysis of this pyro-Glu derivative confirmed the expected trans configuration (Scheme 4): the measured coupling constants are in agreement with the expected preferred conformation of $(3 S, 5 S)$ 7. On the contrary, these data are inconsistent with the $(3 R, 5 S)$ cis configuration for which $\mathrm{H}^{2}$ (and $\mathrm{H}^{3}$ ) would present close values of coupling constants with $\mathrm{H}^{1}$ and $\mathrm{H}^{4}$. These experiments confirmed previous findings with the 4-alkyl-Glu derivatives and were considered to be demonstrative of the general 
Scheme 4. Synthesis and NMR Analysis of Lactam 7

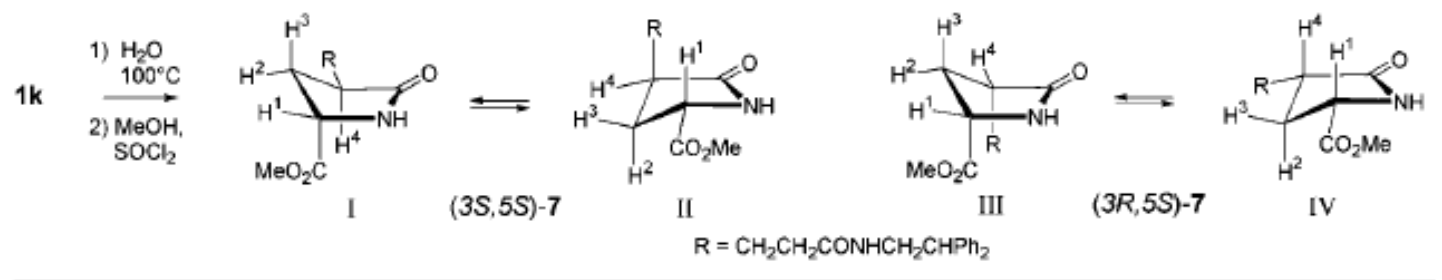

\begin{tabular}{|c|c|c|c|c|c|}
\hline \multirow{2}{*}{$\begin{array}{c}\text { Protons } \\
\text { interaction }\end{array}$} & \multicolumn{4}{|c|}{ Model Coupling constant $(\mathrm{Hz})$ : } & \multirow{2}{*}{$\begin{array}{c}\text { Experimental } \\
\text { Coupling constant }\end{array}$} \\
\hline & $(3 S, 5 S)-7 \mathbf{I}$ & $(3 S, 5 S)-7$ II & $(3 R, 5 S)-7$ III & $(3 R, 5 S)-7$ IV & \\
\hline $\mathrm{H}^{1}-\mathrm{H}^{2}$ & 2.1 & 9.2 & 1.6 & 9.9 & 3.5 \\
\hline $\mathrm{H}^{1}-\mathrm{H}^{3}$ & 9.2 & 7.7 & 8.7 & 7.2 & 9.0 \\
\hline $\mathrm{H}^{2}-\mathrm{H}^{4}$ & 8.8 & 9.2 & 1.3 & 10.1 & 8.8 \\
\hline $\mathrm{H}^{3}-\mathrm{H}^{4}$ & 8,6 & 1,6 & 8.9 & 7,8 & 8.6 \\
\hline
\end{tabular}

${ }^{a}$ Coupling constants were estimated from the preferred calculated conformations I-IV.

stereoselectivity of AAT in favor of the L-2,4-syn configuration of Glu analogues substituted at position 4 .

\section{Pharmacology}

The Glu analogues $\mathbf{2 a}-\mathbf{k}(\mathbf{2} \mathbf{d}$ is exempt) were characterized pharmacologically at human EAAT1, EAAT2, and EAAT3 stably expressed in HEK293 cells using the FLIPR membrane potential (FMP) assay (see Experimental Section for details). The assay was performed essentially as described previously, ${ }^{12}$ and results are summarized in Table 2 . All analogues were either inactive or displayed very weak activities as nonsubstrate inhibitors at EAAT1 and EAAT3. At EAAT2, compounds

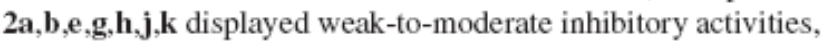
whereas $\mathbf{2 k}$, which holds a bulky substituent on the amide nitrogen ( $N$-2,2-diphenylethyl), displayed a significant preference for inhibition of EAAT2 over EAAT1 and EAAT3, with a midrange micromolar potency $\left(\mathrm{IC}_{50}=75 \mu \mathrm{M}\right)$.

The Glu analogues $\mathbf{2 a - k}$ were also characterized at the EAAT-HEK 293 cell lines in a conventional $\left[{ }^{3} \mathrm{H}\right]-\mathrm{D}-\mathrm{Asp}$ assay (see Experimental Section for details). The inhibition profiles exhibited by the compounds in this assay correlated well with the results from the FMP assay (Table 3). For example, 2k displayed a $10-30$ fold higher inhibitory potency at EAAT2 compared with EAAT1 and EAAT3.

In other studies, dihydrokainic acid (DHK, Table 2) has been shown to be a selective inhibitor of the EAAT2 transporter subtype in medium-range micromolar potency. ${ }^{12,13}$ However, DHK also displays moderate affinity $\left(\mathrm{IC}_{50}=6 \mu \mathrm{M}\right)$ for native kainic acid receptors as well as the cloned homomeric subtypes iGluR5-7 (Table 4). ${ }^{13}$ On the other hand, the well-described EAAT inhibitor, L-threo-benzyloxyaspartate ${ }^{13}$ (TBOA) displays very low affinity for the iGluRs (Table 4 ) but also no selectivity among the EAAT subtypes (Table 2).

These facts prompted us to investigate $2 \mathrm{k}$ at native 2-amino3-(3-hydroxy-5-methyl-4-isoxazolyl)propionic acid (AMPA) receptors, kainic acid (KA, Table 2) receptors, and the $\mathrm{N}$-methylD-aspartic acid (NMDA) receptors in a binding assay using rat brain homogenate. As summarized in Table 4, $\mathbf{2 k}$ displayed low affinities $\left(K_{\mathrm{i}}>100 \mu \mathrm{M}\right)$ for all three groups of native iGluRs. Given the fact that affinities for KA receptor subunits iGluR5-7 are poorly estimated in the $\left[{ }^{3} \mathrm{H}\right] \mathrm{KA}$ binding assay, we further investigated $\mathbf{2 k}$, and $\mathrm{DHK}$, in binding assays at cloned rat iGluR5 -7 subtypes. Whereas DHK displayed low micromolar affinity for iGluR5-7, compound $\mathbf{2 k}$ showed only midrange micromolar affinity for iGluR5 and no affinity for receptor subtypes iGluR6 and iGluR7. We also characterized $2 \mathbf{k}$ in a functional assay at the metabotropic Glu receptors (mGluRs) subtypes mGluR1 and mGluR5 (group I), mGluR2 (group II), and mGluR4 (group III). ${ }^{9}$ In these assays, $2 \mathbf{k}$ proved unable to agonize, antagonize, or modulate any of aforementioned mGluR subtypes. Furthermore, in binding assays at cloned human mGluR2 and mGluR 3 subtypes, 2 k proved without affinity (both $\mathrm{IC}_{50}>1000 \mu \mathrm{M}$ ).

The EAAT2-Inhibitor Pharmacophore. On the basis of several SAR studies, we $\mathrm{e}^{5-8}$ and others ${ }^{14-16}$ have proposed that EAAT substrates and inhibitors, which contain a Glu skeleton, bind in two distinct ways: while substrates bind to the transporter in an extended Glu conformation, the binding conformation of inhibitors is assumed to be equivalent to the folded Glu conformation previously identified as the agonist binding conformation at the iGluRs by X-ray crystallographic studies ${ }^{17}$ and rational ligand design studies. ${ }^{18}$

To address the origin of the inhibitory preference for EAAT2 by $\mathbf{2 k}$, we submitted the compounds $\mathbf{2 j}, \mathbf{2 k}$, and DHK to a stochastic conformational search (see Experimental Section for details). The observed low-energy folded Glu conformations (up to $+1 \mathrm{kcal} / \mathrm{mol}$ ) of $\mathbf{2 j}, \mathbf{2} \mathbf{k}$, and DHK were superimposed by fitting the ammonium and the two carboxylate groups (Figure 1). Interestingly, the isopropyl group of DHK, which is believed to be the molecular feature determining the EAAT2 subtype selectivity of the compound, ${ }^{5}$ does not occupy the same area in space as the bulky substituent on the amide nitrogen $(\mathrm{N}-2,2-$ diphenylethyl) of $\mathbf{2 k}$. This suggests that the EAAT2 preference displayed by $\mathbf{2 k}$ arises from a different molecular mechanism than that of DHK. The lack of exact three-dimensional structural information of EAAT2 makes it impossible for us to point out the specific structural features of neither the EAAT2 protein nor the $\mathbf{2 k}$ ligand, which underlie the EAAT2 selectivity profile of this novel compound.

\section{Conclusion}

In conclusion, we have described a chemo-enzymatic enantioselective synthetic route toward compounds $\mathbf{2 g}-\mathbf{k}$ and presented the pharmacological characteristics of Glu analogues $\mathbf{2 a}-\mathbf{k}$ at human EAAT1-3. Notably, 2k was found to be a novel inhibitor with significant preference for EAAT2 over EAAT1 and EAAT3. In comparison with the often used EAAT2selective inhibitor, DHK, compound $\mathbf{2 k}$ displays a significantly higher degree of selectivity toward EAAT2 over iGluRs and mGluRs. Thus $2 \mathbf{k}$ may be a more useful pharmacological tool 
Table 2. Inhibition of Glu-Induced Depolarization in EAAT1-, EAAT2-, and EAAT3-HEK293 Cells in the FMP Assay ${ }^{a}$<smiles>C=C(C)C1CN[C@@H](C(=O)O)C1CC(=O)O</smiles>

KA<smiles>CC(C)[C@H]1CN[C@@H](C(=O)O)[C@H]1CC(=O)O</smiles>

DHK<smiles>N[14C](=O)[14C](=O)O[14C](=O)O</smiles>

L-TBOA

\begin{tabular}{|c|c|c|c|c|}
\hline & $\mathbf{R}$ & EAAT1 & EAAT2 & EAAT3 \\
\hline Glu & $\mathrm{H}$ & $7.9[5.1 \pm 0.03]$ & $21[4.7 \pm 0.02]$ & $9.9[5.0 \pm 0.02]$ \\
\hline $2 a$ & $\widehat{\overbrace O \mathrm{OH}}$ & $\sim 3000[\sim 2.5]$ & $\sim 300[\sim 3.5]$ & $\sim 3000[\sim 2.5]$ \\
\hline $2 \mathbf{b}$ & & $\sim 1000[\sim 3]$ & $\sim 300[\sim 3.5]$ & $\sim 3000[\sim 2.5]$ \\
\hline $2 c$ & & $>3000[<2.5]$ & $>3000[<2.5]$ & $>3000[<2.5]$ \\
\hline $2 f$ & & $\sim 3000[\sim 2.5]$ & $\sim 3000[\sim 2.5]$ & $\sim 3000[\sim 2.5]$ \\
\hline $2 e$ & & $\sim 1000[\sim 3]$ & $\sim 300[\sim 3.5]$ & $>1000[<3]$ \\
\hline $2 \mathrm{~g}$ & & $\sim 3000[\sim 2.5]$ & $\sim 1000[\sim 3]$ & $>3000[\sim 2.5]$ \\
\hline $2 \mathrm{~h}$ & & $>1000[<3]$ & $\sim 1000[\sim 3]$ & $>1000[<3]$ \\
\hline $2 \mathrm{i}$ & & $>3000[<2.5]$ & $\sim 3000[\sim 2.5]$ & $\sim 3000[\sim 2.5]$ \\
\hline $2 \mathrm{j}$ & & $\sim 1000[\sim 3]$ & $\sim 300[\sim 3.5]$ & $\sim 1000[\sim 3]$ \\
\hline $2 k$ & & $\sim 1000[\sim 3]$ & $75[4.1 \pm 0.05]$ & $\sim 1000[\sim 3]$ \\
\hline $\mathrm{DHK}^{b}$ & - & $>3000[<2.5]$ & $89[4.1 \pm 0.05]$ & $>3000[<2.5]$ \\
\hline $\mathrm{DL}_{-\mathrm{TBOA}^{b}}$ & - & $2.9[5.5 \pm 0.09]$ & $2.2[5.7 \pm 0.07]$ & $9.3[5.0 \pm 0.06]$ \\
\hline
\end{tabular}

\footnotetext{
${ }^{a}$ The $\mathrm{IC}_{90}$ values of the nonsubstrate inhibitors were obtained using $\mathrm{EC}_{90}-\mathrm{EC}_{90}$ concentrations of Glu at the three EAAT subtypes. The $\mathrm{K}_{\mathrm{m}}$ values for substrates (bold) and $\mathrm{IC}_{90}$ values for inhibitors, are given in $\mu \mathrm{M}$ (with $\mathrm{p} K_{\mathrm{m}} \pm \mathrm{SEM}$ and $\mathrm{p} I C_{90} \pm \mathrm{SEM}$ values in brackets, respectively). ${ }^{b} \mathrm{Values}$ taken from
} ref 12 .

for the investigation of the physiological roles governed by the EAAT2. The design and synthesis of analogues of $\mathbf{2 k}$, which may improve potency, is currently in progress in our laboratories.

\section{Experimental Section}

Chemistry. Melting points were determined on a Reichert hotstage apparatus and are uncorrected. IR spectra were recorded on a Perkin-Elmer 801 spectrophotometer. ${ }^{1} \mathrm{H}$ and ${ }^{13} \mathrm{C}$ NMR spectra were recorded on a Bruker Avance $400 \mathrm{MHz}$ spectrometer. Chemical shifts are reported in ppm $(\delta)$ relative to TMS as internal standard. HRMS were recorded on a q-tof Micromass spectrometer. Optical rotations were determined with a JASCO DIP 370 polarimeter and are reported at the sodium D line $(589 \mathrm{~nm})$. Elemental analyses were performed at the Service Central d'Analyze du CNRS, Solaize, France. Silicagel 60 (Merck, 40-63 $\mu \mathrm{m}$ ) and precoated $\mathrm{F}_{254}$ plates were used for column and TLC chromatography. All solvents were purified by distillation following usual procedures. Cysteine sulfinic acid was prepared from cystine following a described procedure. ${ }^{19}$ Bovine heart malic dehydrogenase and rabbit muscle lactic dehydrogenase were purchased from Sigma. Escherichia. coli AAT was produced and purified following described procedures from overexpressing $E$. coli strains JM103 transformed with pUC119-aspC (AAT). ${ }^{20}$ Enzyme kinetic measurements were performed at $25{ }^{\circ} \mathrm{C}$ in $0.1 \mathrm{M}$ potassium phosphate buffer, $\mathrm{pH} 7.6, \mathrm{Asp}(40 \mathrm{mM}), \mathrm{NADH}(0.2 \mathrm{mM})$, ketoacid substrate $(0.1-10 \mathrm{mM})$, AAT $(0.05 \mathrm{UI})$, and malic dehydrogenase (2 UI) in a total volume of $1 \mathrm{~mL}$. Rates were calculated from the OD linear decay at $340 \mathrm{~nm}$ using $\epsilon_{\mathrm{NADH}}=6220 \mathrm{~cm}^{-1} \cdot \mathrm{M}^{-1}$.

Dimethyl 4-Aminocyclohex-3-ene-1-3-dicarboxylate 4g. To a solution of $3^{10}(1 \mathrm{~g}, 4.6 \mathrm{mmol})$ in $\mathrm{MeOH}(5 \mathrm{~mL})$, was added a $20 \%$ aqueous solution of $\mathrm{NH}_{3}(1.3 \mathrm{~mL}, 13.8 \mathrm{mmol})$. The reaction mixture was stirred at room temperature for $48 \mathrm{~h}$. After addition of brine $(10 \mathrm{~mL})$, the aqueous solution was extracted with AcOEt $(3 \times 10 \mathrm{~mL})$. The combined organic layers were dried over $\mathrm{MgSO}_{4}$ 
Table 3. Inhibition of $\left[{ }^{3} \mathrm{H}\right]-\mathrm{D}-A$ sp Uptake in EAAT1-, EAAT2-, and EAAT3-HEK293 Cells ${ }^{a}$

\begin{tabular}{lccl}
\hline & EAAT1 & EAAT2 & \multicolumn{1}{c}{ EAAT3 } \\
\hline Glu & $35[4.5 \pm 0.04]$ & $62[4.2 \pm 0.03]$ & $51[4.3 \pm 0.02]$ \\
$\mathbf{2 a}$ & $\sim 3000[\sim 2.5]$ & $140[3.9 \pm 0.05]$ & $\sim 3000[\sim 2.5]$ \\
$\mathbf{2 b}$ & $450[3.3 \pm 0.05]^{b}$ & $290[3.5 \pm 0.03]^{b}$ & $1000-3000[2.5-3]$ \\
$\mathbf{2 c}$ & $>3000[<2.5]$ & $>3000[<2.5]$ & $>3000[<2.5]$ \\
$\mathbf{2 f}$ & $>3000[<2.5]$ & $>3000[<2.5]$ & $>3000[<2.5]$ \\
$\mathbf{2 e}$ & $1000-3000[2.5-3]$ & $180[3.8 \pm 0.04]$ & $\sim 3000[\sim 2.5]$ \\
$\mathbf{2 g}$ & $>3000[<2.5]$ & $290[3.5 \pm 0.04]^{b}$ & $>3000[<2.5]$ \\
$\mathbf{2 h}$ & $>3000[<2.5]$ & $680[3.2 \pm 0.05]^{b}>3000[<2.5]$ \\
$\mathbf{2 i}$ & $>3000[<2.5]$ & $1000-3000[2.5-3]$ & $>3000[<2.5]$ \\
$\mathbf{2 j}$ & $\sim 1000[\sim 3]$ & $410[3.4 \pm 0.05]^{b} \sim 3000[\sim 2.5]$ \\
$\mathbf{2 k}$ & $1000-3000[2.5-3]$ & $95[4.0 \pm 0.04]$ & $\sim 3000[\sim 2.5]$ \\
\hline
\end{tabular}

${ }^{a}$ The $K_{\mathrm{i}}$ values are given in $\mu \mathrm{M}$ with $\mathrm{p} K_{\mathrm{i}} \pm \mathrm{SEM}$ values in brackets. ${ }^{b}$ The specific $\left[{ }^{3} \mathrm{H}\right]$-D-Asp uptake at the EAAT was not completely inhibited by the maximal concentration of the compound $(3 \mathrm{mM})$, and thus the $K_{\mathrm{i}}$ value is determined from the fit of the concentration-inhibition curve for the compound.

and concentrated under reduced pressure. $4 \mathrm{~g}$ was isolated as a white solid $(0.98 \mathrm{~g})$ and used in the next reaction without further purification; mp $56^{\circ} \mathrm{C}$ (lit. $\left.{ }^{21} \mathrm{mp} \mathrm{58-60.5}{ }^{\circ} \mathrm{C}\right)$. ${ }^{1} \mathrm{H}$ NMR $(400 \mathrm{MHz}$, $\left.\mathrm{D}_{2} \mathrm{O}\right) \delta 7.5-4.5(2 \mathrm{H}, \mathrm{s}$, broad), $3.69(3 \mathrm{H}, \mathrm{s}), 3.68(3 \mathrm{H}, \mathrm{s}), 2.66$ (1H, dd, $J=5.1$ and $15.6 \mathrm{~Hz}), 2.52(1 \mathrm{H}, \mathrm{tdd}, J=2.9,5.3$ and $10.3 \mathrm{~Hz}) 2.40-2.30(2 \mathrm{H}, \mathrm{m}), 2.25(1 \mathrm{H}$, ddd, $J=3.6,5.7$ and 16.8 $\mathrm{Hz}), 2.00(1 \mathrm{H}, \mathrm{m}), 1.74(1 \mathrm{H}, \mathrm{tdd}, J=5.8,10.9$ and $13.0 \mathrm{~Hz}),{ }^{13} \mathrm{C}$ NMR $\left(100 \mathrm{MHz}, \mathrm{D}_{2} \mathrm{O}\right) \delta 175.8,170.2,155.9,89.9,51.7,50.4$, 39.4, 29.4, 25.9, 24.2.

General Procedure for the Synthesis of $\mathbf{4 h - k}$. To a solution of $3(1 \mathrm{~g}, 4.6 \mathrm{mmol})$ in anhydrous toluene $(4 \mathrm{~mL})$ was added $4 \AA$ molecular sieves $(1 \mathrm{~g})$ and the amine $(6.9 \mathrm{mmol})$. For $4 \mathrm{~h}$ synthesis, a $2 \mathrm{M}$ solution of $\mathrm{MeNH}_{2}$ in THF was used. In the case of $4 \mathrm{k}$ synthesis, $4.6 \mathrm{mmol}$ of $\mathrm{Ph}_{2} \mathrm{CHCH}_{2} \mathrm{NH}_{2}$ and $40 \mathrm{~mL}$ of toluene were used. The reaction mixture was stirred at room temperature for $48 \mathrm{~h}$. After filtration, the solution was concentrated under reduced pressure. Compounds $\mathbf{4 h}-\mathbf{k}$ were isolated as white solids ( $4 \mathbf{h}$ and $\mathbf{4 k}$ ) or as colorless liquids $(\mathbf{4 i}$ and $\mathbf{4 j})$ and were used in the next reaction without further purification. In every case, ${ }^{1} \mathrm{H}$ NMR analysis indicated a yield over $90 \%$.

Dimethyl 4-Methylaminocyclohex-3-ene-1-3-dicarboxylate 4 h. Melting point $68-70^{\circ} \mathrm{C} .{ }^{1} \mathrm{H}$ NMR $\left(400 \mathrm{MHz}, \mathrm{D}_{2} \mathrm{O}\right) \delta 8.76(1 \mathrm{H}$, $\mathrm{s}$, broad), $3.61(3 \mathrm{H}, \mathrm{s}), 3.57(3 \mathrm{H}, \mathrm{s}), 2.79(3 \mathrm{H}, \mathrm{d}, J=5.2 \mathrm{~Hz}), 2.66$ $(1 \mathrm{H}$, dd, $J=4.5$ and $15.0 \mathrm{~Hz}), 2.50-2.15(4 \mathrm{H}, \mathrm{m}), 1.98(1 \mathrm{H}, \mathrm{m})$, $1.65(1 \mathrm{H}, \mathrm{m}) .{ }^{13} \mathrm{C}$ NMR $\left(100 \mathrm{MHz}, \mathrm{D}_{2} \mathrm{O}\right) \delta 175.6,170.4,159.1$, $87.4,51.6,50.1,39.2,29.0,29.4,26.4,25.2,24.2$.

Dimethyl 4-Propylaminocyclohex-3-ene-1-3-dicarboxylate 4 i. ${ }^{1} \mathrm{H}$ NMR $\left(400 \mathrm{MHz}, \mathrm{D}_{2} \mathrm{O}\right) \delta 8.93(1 \mathrm{H}, \mathrm{s}$, broad $), 3.69(3 \mathrm{H}, \mathrm{s}), 3.66$ $(3 \mathrm{H}, \mathrm{s}), 3.11(2 \mathrm{H}, \mathrm{m}), 2.68(1 \mathrm{H}, \mathrm{dd}, J=4.8$ and $15.0 \mathrm{~Hz})$, $2.56-2.24(4 \mathrm{H}, \mathrm{m}), 2.05(1 \mathrm{H}, \mathrm{m}), 1.70(1 \mathrm{H}, \mathrm{tdd}, J=5.8,11.0$ and $13.1 \mathrm{~Hz}), 1.58(2 \mathrm{H}$, hex, $J=7.2 \mathrm{~Hz}), 0.97(3 \mathrm{H}, \mathrm{t}, J=7.3 \mathrm{~Hz})$. ${ }^{13} \mathrm{C}$ NMR $\left(100 \mathrm{MHz}, \mathrm{D}_{2} \mathrm{O}\right) \delta 175.7,170.8,158.7,87.1,51.7,50.3$, $44.1,39.3,26.4,25.6,24.3,23.5,11.5$.

Dimethyl 4-Benzylaminocyclohex-3-ene-1-3-dicarboxylate $4 \mathrm{j} .{ }^{1} \mathrm{H}$ NMR (400 MHz, D 20$) \delta 9.31(1 \mathrm{H}, \mathrm{s}$, broad), 7.35-7.10 $(5 \mathrm{H}, \mathrm{m})$, $4.37(2 \mathrm{H}, \mathrm{m}), 3.66(6 \mathrm{H}, \mathrm{s}), 2.68(1 \mathrm{H}, \mathrm{dd}, J=4.4$ and $14.8 \mathrm{~Hz})$, $2.55-2.35(3 \mathrm{H}, \mathrm{m}), 2.24(1 \mathrm{H}$, ddd, $J=6.3,10.8$ and $17.5 \mathrm{~Hz})$, $1.98(1 \mathrm{H}, \mathrm{m}), 1.66(1 \mathrm{H}, \mathrm{tdd}, J=5.8,10.9$ and $13.1 \mathrm{~Hz}) .{ }^{13} \mathrm{C}$ NMR $\left(100 \mathrm{MHz}, \mathrm{D}_{2} \mathrm{O}\right) \delta 175.6,170.7,158.4,139.1,128.8,127.2,126.7$, $88.7,51.7,50.5,46.2,39.3,26.4,25.4,24.3$.

Dimethyl 4-(2,2-Diphenylethylamino)cyclohex-3-ene-1-3-dicarboxylate $4 \mathrm{k}$. Melting point $145^{\circ} \mathrm{C}$. ${ }^{1} \mathrm{H}$ NMR $\left(400 \mathrm{MHz}, \mathrm{D}_{2} \mathrm{O}\right) \delta$ $8.83(1 \mathrm{H}, \mathrm{t}, J=5.0 \mathrm{~Hz}), 7.25-7.10(10 \mathrm{H}, \mathrm{m}), 4.06(1 \mathrm{H}, \mathrm{t}, J=7.2$ $\mathrm{Hz}), 3.71(2 \mathrm{H}, \mathrm{m}), 3.60(3 \mathrm{H}, \mathrm{s}), 3.51(3 \mathrm{H}, \mathrm{s}), 2.56(1 \mathrm{H}, \mathrm{dd}, J=$ 4.2 and $14.7 \mathrm{~Hz}), 2.40-2.15(3 \mathrm{H}, \mathrm{m}), 2.08(1 \mathrm{H}, \mathrm{m}), 1.90(1 \mathrm{H}, \mathrm{m})$, $1.55(1 \mathrm{H}, \mathrm{m}) .{ }^{13} \mathrm{C}$ NMR $\left(100 \mathrm{MHz}, \mathrm{D}_{2} \mathrm{O}\right) \delta 175.7,170.4,157.7$, $141.9,128.7,128.1,126.8,88.2,52.1,51.7,50.4,47.4,39.2,26.5$, $25.7,24.3$.

General ozonolysis procedure for the synthesis of $5 \mathrm{~g}-\mathrm{k}$. A solution of enamine $\mathbf{4 g}-\mathbf{k}$ (approximately $4 \mathrm{mmol}$ ) in anhydrous $\mathrm{CH}_{2} \mathrm{Cl}_{2}(40 \mathrm{~mL})$ was treated at $-70{ }^{\circ} \mathrm{C}$ with a mixture of $\mathrm{O}_{2}$ and $\mathrm{O}_{3}$ at a rate of $10 \mathrm{~L} / \mathrm{h}$ until saturation (blue coloration of the solution). After $30 \mathrm{~min}$, the excess ozone was eliminated by oxygen bubbling. Triphenylphosphine $(1.2 \mathrm{~g}, 4.5 \mathrm{mmol})$ was added, and the reaction mixture was allowed to warm to room temperature. The solution was washed with water $(20 \mathrm{~mL})$, brine $(20 \mathrm{~mL})$, dried over $\mathrm{MgSO}_{4}$, and concentrated under reduced pressure. Flash chromatography (eluent, cyclohexane-AcOEt, 7:3 to AcOEt-MeOH, $9: 1, \mathrm{v} / \mathrm{v})$ afforded $\mathbf{5} \mathrm{g}-\mathbf{k}$ as colorless liquids. $\mathbf{6}$ was also isolated as a 1:2 mixture of isomers.

Dimethyl 2-(3-Amino-3-oxopropyl)-4-oxoglutarate 5g. Yield 55\% from 3. IR (neat film) 3453, 3363, 3206, 1730, $1667 \mathrm{~cm}^{-1} \cdot{ }^{1} \mathrm{H}$ NMR (400 MHz, CDCl $) \delta 5.73(2 \mathrm{H}, \mathrm{s}$, broad), $3.86(3 \mathrm{H}, \mathrm{s}), 3.67$ $(3 \mathrm{H}, \mathrm{s}), 3.31(1 \mathrm{H}, \mathrm{dd}, J=10.1$ and $20.0 \mathrm{~Hz}) 2.96(1 \mathrm{H}, \mathrm{dd}, J=4.9$ and $20.0 \mathrm{~Hz}), 2.97(1 \mathrm{H}, \mathrm{m}), 2.29(2 \mathrm{H}, \mathrm{m}), 1.95(2 \mathrm{H}, \mathrm{m}) .{ }^{13} \mathrm{C}$ NMR $\left(100 \mathrm{MHz} \mathrm{CDCl}_{3}\right) \delta 191.9,174.3,174.2,160.8,53.1,52.2,40.9$, $39.2,32.8,26.9$. HRMS (ES+) $m / z 268.0798\left([\mathrm{M}+\mathrm{Na}]^{+}\right.$, $\mathrm{C}_{10} \mathrm{H}_{15} \mathrm{NaNO}_{6}$ requires 268.0797). Anal. $\left(\mathrm{C}_{10} \mathrm{H}_{15} \mathrm{NO}_{6}\right): \mathrm{C}, \mathrm{H}, \mathrm{N}$.

Dimethyl 2-(3-Methylamino-3-oxopropyl)-4-oxoglutarate 5h. Yield $35 \%$ from 3. IR (neat film) 3393, 3313, 3103, 1735, 1652 $\mathrm{cm}^{-1} .{ }^{1} \mathrm{H}$ NMR $\left(400 \mathrm{MHz}, \mathrm{CDCl}_{3}\right) \delta 6.03(1 \mathrm{H}, \mathrm{s}$, broad), 3.88 $(3 \mathrm{H}, \mathrm{s}), 3.67(3 \mathrm{H}, \mathrm{s}), 3.32(1 \mathrm{H}, \mathrm{dd}, J=10.2$ and $19.8 \mathrm{~Hz}) 2.96$ $(1 \mathrm{H}, \mathrm{dd}, J=4.6$ and $19.8 \mathrm{~Hz}), 2.96(1 \mathrm{H}, \mathrm{m}), 2.81(3 \mathrm{H}, \mathrm{d}, J=4.8$ $\mathrm{Hz}), 2.23(2 \mathrm{H}, \mathrm{m}), 1.97(2 \mathrm{H}, \mathrm{m}) .{ }^{13} \mathrm{C} \mathrm{NMR}\left(100 \mathrm{MHz}, \mathrm{CDCl}_{3}\right) \delta$ $191.9,174.4,172.4,160.8,53.1,52.1,40.9,39.2,33.6,27.3,26.3$. HRMS (ES+) $m / z 282.0968\left([\mathrm{M}+\mathrm{Na}]^{+}, \mathrm{C}_{11} \mathrm{H}_{17} \mathrm{NaNO}_{6}\right.$ requires 282.0954). Anal. $\left(\mathrm{C}_{11} \mathrm{H}_{17} \mathrm{NO}_{6}\right): \mathrm{C}, \mathrm{H}, \mathrm{N}$.

Dimethyl 2-(3-Propylamino-3-oxopropyl)-4-oxoglutarate 5i. Yield $35 \%$ from 3. IR (neat film) 3389, 3306, 3100, 1732, 1648 $\mathrm{cm}^{-1}$. ${ }^{1} \mathrm{H}$ NMR $\left(400 \mathrm{MHz}, \mathrm{CDCl}_{3}\right) \delta 5.64(1 \mathrm{H}, \mathrm{s}$, broad $), 3.85$ $(3 \mathrm{H}, \mathrm{s}), 3.66(3 \mathrm{H}, \mathrm{s}), 3.30(1 \mathrm{H}, \mathrm{dd}, J=10.1$ and $19.7 \mathrm{~Hz}), 3.18$ $(2 \mathrm{H}, \mathrm{q}, J=6.8 \mathrm{~Hz}), 2.94(1 \mathrm{H}, \mathrm{dd}, J=4.6$ and $19.8 \mathrm{~Hz}), 2.92(1 \mathrm{H}$, m), $2.20(2 \mathrm{H}, \mathrm{m}), 1.93(2 \mathrm{H}, \mathrm{m}), 1.49(2 \mathrm{H}$, hex, $J=7.2 \mathrm{~Hz}), 0.89$ $(3 \mathrm{H}, \mathrm{t}, J=7.4 \mathrm{~Hz}) .{ }^{13} \mathrm{C}$ NMR $\left(100 \mathrm{MHz}, \mathrm{CDCl}_{3}\right) \delta 191.9,174.4$, $171.5,160.8,53.1,52.1,41.3,40.9,39.2,33.4,27.4,22.8,11.3$. HRMS (ES+) $m / z 310.1274\left([\mathrm{M}+\mathrm{Na}]^{+}, \mathrm{C}_{13} \mathrm{H}_{21} \mathrm{NaNO}_{6}\right.$ requires 310.1267). Anal. $\left(\mathrm{C}_{11} \mathrm{H}_{17} \mathrm{NO}_{6}\right)$ : C, H, N.

Dimethyl 2-(3-Benzylamino-3-oxopropyl)-4-oxoglutarate 5j. Yield $43 \%$ from 3. IR (neat film) $3384,3303,1734,1654 \mathrm{~cm}^{-1}$. ${ }^{1} \mathrm{H}$ NMR $\left(400 \mathrm{MHz}, \mathrm{CDCl}_{3}\right) \delta 7.28(5 \mathrm{H}, \mathrm{m}), 6.19(1 \mathrm{H}, \mathrm{s}$, broad), $4.39(2 \mathrm{H}, \mathrm{d}, J=5.7 \mathrm{~Hz}), 3.85(3 \mathrm{H}, \mathrm{s}), 3.64(3 \mathrm{H}, \mathrm{s}), 3.29(1 \mathrm{H}$, dd, $J=10.2$ and $19.8 \mathrm{~Hz}), 2.94(1 \mathrm{H}, \mathrm{m}), 2.93(1 \mathrm{H}, \mathrm{dd}, J=4.4$ and $19.8 \mathrm{~Hz}), 2.25(2 \mathrm{H}, \mathrm{m}), 1.96(2 \mathrm{H}, \mathrm{m}) .{ }^{13} \mathrm{C} \mathrm{NMR}\left(100 \mathrm{MHz}, \mathrm{CDCl}_{3}\right)$ $\delta 191.9,174.4,171.5,160.8,138.2,128.7,127.8,127.5,53.1,52.1$, $43.6,40.9,39.2,33.6,27.3$. HRMS (ES+) $\mathrm{m} / \mathrm{z} 358.1267([\mathrm{M}+$ $\mathrm{Na}]^{+}, \mathrm{C}_{17} \mathrm{H}_{21} \mathrm{NaNO}_{6}$ requires 358.1267). Anal. $\left(\mathrm{C}_{11} \mathrm{H}_{17} \mathrm{NO}_{6}\right): \mathrm{C}, \mathrm{H}$, N.

Dimethyl 2-(2,2-Diphenylethylamino-3-oxopropyl)-4-oxoglutarate 5k. Yield $25 \%$ from 3. IR $\left(\mathrm{CCl}_{4}\right) 3450,1735,1668 \mathrm{~cm}^{-1}$ ${ }^{1} \mathrm{H}$ NMR $\left(400 \mathrm{MHz}^{\mathrm{CDCl}}\right)_{3} \delta 7.25(10 \mathrm{H}, \mathrm{m}), 5.50(1 \mathrm{H}, \mathrm{s}$, broad), $4.18(1 \mathrm{H}, \mathrm{t}, J=7.8 \mathrm{~Hz}), 3.90(2 \mathrm{H}, \mathrm{m}), 3.87(3 \mathrm{H}, \mathrm{s}), 3.62(3 \mathrm{H}, \mathrm{s})$, $3.26(1 \mathrm{H}$, dd, $J=8.8$ and $18.6 \mathrm{~Hz}), 2.89(1 \mathrm{H}, \mathrm{dd}, J=4.3$ and $18.5 \mathrm{~Hz}), 2.83(1 \mathrm{H}, \mathrm{m}), 2.11(2 \mathrm{H}, \mathrm{m}), 1.85(2 \mathrm{H}, \mathrm{m}) .{ }^{13} \mathrm{C}$ NMR $\left(100 \mathrm{MHz} \mathrm{CDCl}_{3}\right) \delta 191.8,174.3,171.6,160.8,141.8,128.7$, $128.0,126.8,53.1,52.0,50.6,43.8,40.9,39.1,33.6,27.2$. HRMS (ES+) $m / z$ 426.1933 $\left([\mathrm{M}+\mathrm{H}]^{+}, \mathrm{C}_{24} \mathrm{H}_{28} \mathrm{NO}_{6}\right.$ requires 426.1917). Anal. $\left(\mathrm{C}_{11} \mathrm{H}_{17} \mathrm{NO}_{6}, 0.25 \mathrm{H}_{2} \mathrm{O}\right): \mathrm{C}, \mathrm{H}, \mathrm{N}$.

Dimethyl 3-Hydroxy-4-oxocyclohexanedicarboxylate 6. Yield $20-50 \%$. IR (neat) $3456,1728 \mathrm{~cm}^{-1} \cdot{ }^{1} \mathrm{H} \mathrm{NMR}\left(400 \mathrm{MHz}, \mathrm{CDCl}_{3}\right.$ ) d $4.39(1 \mathrm{H}, \mathrm{s}), 4.00(1 \mathrm{H}, \mathrm{s}), 3.83(3 \mathrm{H}, \mathrm{s}), 3.78(3 \mathrm{H}, \mathrm{s}), 3.70(2 \times$ $3 \mathrm{H}, \mathrm{s}), 3.08(2 \times 1 \mathrm{H}, \mathrm{m}), 2.89(2 \times 1 \mathrm{H}, \mathrm{m}), 2.67(1 \mathrm{H}, \mathrm{m}), 2.50(3$ $\times 1 \mathrm{H}, \mathrm{m}), 2.38-2.23(3 \times 1 \mathrm{H}, \mathrm{m}), 2.03-1.81(3 \times 1 \mathrm{H}, \mathrm{m}) .{ }^{13} \mathrm{C}$ NMR $\left(100 \mathrm{MHz}_{2} \mathrm{CDCl}_{3}\right) \delta 205.7,205.2,174.2,173.4,171.9,169.8$, $79.7,78.9,53.3,53.2,52.2,52.0,39.5,39.1,37.7,37.1,37.0,36.2$, $29.1,28.4$. HRMS (ES+) $m / z 253.0674\left([\mathrm{M}+\mathrm{Na}]^{+}, \mathrm{C}_{10} \mathrm{H}_{14} \mathrm{NaO}_{6}\right.$ requires 253.0688).

General Procedure for the Synthesis of Dilithium Oxoglutarate $\mathbf{1 g}-\mathbf{k}$. To a solution of $\mathbf{5 g}-\mathbf{k}(2 \mathrm{mmol})$ in $\mathrm{MeOH}(10 \mathrm{~mL})$ was added dropwise a $0.4 \mathrm{M}$ solution of $\mathrm{LiOH}(10.5 \mathrm{~mL}, 4.2 \mathrm{mmol})$. The mixture was stirred at room temperature for 5 to $15 \mathrm{~h}$, until completion. After evaporation of $\mathrm{MeOH}$, the $\mathrm{pH}$ of the aqueous solution was adjusted to 7.6 by addition of dowex $50 \mathrm{WX} 8$ resin $\left(\mathrm{H}^{+}\right.$form). The resin was removed by filtration before evaporation 
Table 4. Binding Affinities of 2k, DHK, and TBOA at Native AMPA-, KA-, NMDA Receptors (Rat Synaptosomes) as well as at Rat Homomeric iGluR5-7

\begin{tabular}{lcccccc}
\hline compound & AMPA IC $_{50}(\mu \mathrm{M})$ & $\mathrm{KA} \mathrm{IC}_{50}(\mu \mathrm{M})$ & NMDA IC $_{50}(\mu \mathrm{M})$ & $\mathrm{iGluR5} \mathrm{K}_{\mathbf{i}}(\mu \mathrm{M})$ & $\mathrm{iGluR6} \mathrm{K}_{\mathbf{i}}(\mu \mathrm{M})$ & $\mathrm{iGluR7} \mathrm{K}_{\mathbf{i}}(\mu \mathrm{M})$ \\
\hline $\mathbf{2 k}$ & $>100$ & $>100$ & $>100$ & $37.2[4.44 \pm 0.05]$ & $>100$ \\
DHK & $1100^{a}$ & $6^{a}$ & $350^{a}$ & $8.18[5.09 \pm 0.02]$ & $12.3[4.92 \pm 0.05]$ & $0.376[6.44 \pm 0.07]$ \\
TBOA & $>1000^{a}$ & $550^{a}$ & $470^{a}$ & nd & nd & nd \\
\hline
\end{tabular}

${ }^{a}$ Data are taken from ref 13 . Mean $\mathrm{p} K_{\mathrm{i}}(\mathrm{M}) \pm \mathrm{SEM}$ is given in square brackets (3-5 experiments conducted in triplicate). Hill values were unity for DHK and $2 \mathrm{k}$ at iGluR5 -7 . nd: no data available.

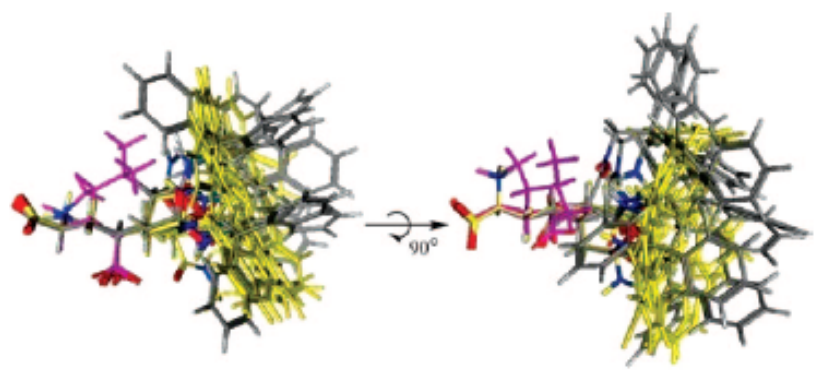

Figure 1. Superimposition of calculated low-energy conformations (up to $+1 \mathrm{kcal} / \mathrm{mol}$ ) of $2 \mathbf{k}$ (type code), $2 \mathbf{j}$ (yellow), and DHK (purple), by fitting ammonium groups and two carboxylate groups.

of the water under reduced pressure. $2 \mathrm{~g}-\mathbf{k}$ were isolated in quantitative yield as white solids.

Dilithium 2-(3-Amino-3-oxopropyl)-4-oxoglutarate 1g. ${ }^{1} \mathrm{H}$ NMR $\left(400 \mathrm{MHz}, \mathrm{D}_{2} \mathrm{O}\right) \delta 3.02(1 \mathrm{H}$, dd, $J=9.0$ and $19.5 \mathrm{~Hz}), 2.84(1 \mathrm{H}$, dd, $J=6.7$ and $19.2 \mathrm{~Hz}), 2.61(1 \mathrm{H}, \mathrm{m}), 2.24(2 \mathrm{H}, \mathrm{m}), 1.74(2 \mathrm{H}, \mathrm{m})$. ${ }^{13} \mathrm{C}$ NMR $\left(100 \mathrm{MHz}, \mathrm{D}_{2} \mathrm{O}\right) \delta 204.3,182.6,179.2,167.9,42.6$, $42.0,33.0,28.2$. HRMS (ES-) $m / z 216.0509\left([\mathrm{M}-2 \mathrm{Li}+\mathrm{H}]^{-}\right.$, $\mathrm{C}_{8} \mathrm{H}_{10} \mathrm{NO}_{6}$ requires 216.0508 ).

Dilithium 2-(3-Methylamino-3-oxopropyl)-4-oxoglutarate $1 \mathrm{~h} .{ }^{1} \mathrm{H}$ NMR $\left(400 \mathrm{MHz}, \mathrm{D}_{2} \mathrm{O}\right) \delta 3.02(1 \mathrm{H}, \mathrm{dd}, J=8.8$ and $18.4 \mathrm{~Hz}), 2.83$ $(1 \mathrm{H}, \mathrm{dd}, J=5.4$ and $18.6 \mathrm{~Hz}), 2.68(3 \mathrm{H}, \mathrm{s}), 2.59(1 \mathrm{H}, \mathrm{m}), 2.21$ $(2 \mathrm{H}, \mathrm{m}), 1.73(2 \mathrm{H}, \mathrm{m}) .{ }^{13} \mathrm{C}$ NMR $\left(100 \mathrm{MHz}, \mathrm{D}_{2} \mathrm{O}\right) \delta 204.4,182.9$, $176.5,169.7,42.6,42.0,33.7,28.4,25.8$. HRMS (ES-) $\mathrm{m} / \mathrm{z}$ $236.0761\left(\left[\mathrm{M}-2 \mathrm{Li}+\mathrm{H}^{-}, \mathrm{C}_{9} \mathrm{H}_{12} \mathrm{NO}_{6}\right.\right.$ requires 236.0746$)$.

Dilithium 2-(3-Propylamino-3-oxopropyl)-4-oxoglutarate 1i. ${ }^{1} \mathrm{H}$ NMR $\left(400 \mathrm{MHz}, \mathrm{D}_{2} \mathrm{O}\right) \delta 3.12(3 \mathrm{H}, \mathrm{t}, J=6.8 \mathrm{~Hz}), 3.05(1 \mathrm{H}$, dd, $J=8.4$ and $18.4 \mathrm{~Hz}), 2.86(1 \mathrm{H}$, dd, $J=5.2$ and $18.4 \mathrm{~Hz}), 2.62$ $(1 \mathrm{H}, \mathrm{m}), 2.24(2 \mathrm{H}, \mathrm{m}), 1.75(2 \mathrm{H}, \mathrm{m}), 1.50(2 \mathrm{H}$, hex, $J=7.4 \mathrm{~Hz})$, $0.87(3 \mathrm{H}, \mathrm{t}, J=7.4 \mathrm{~Hz}) .{ }^{13} \mathrm{C}$ NMR $\left(100 \mathrm{MHz}, \mathrm{D}_{2} \mathrm{O}\right) \delta 204.4$, 181.6, 175.7, 170.8, 41.5, 41.2, 33.7, 27.9, 21.7, 10.6. HRMS (ES-) $m / z 258.0995\left([\mathrm{M}-2 \mathrm{Li}+\mathrm{H}]^{-}, \mathrm{C}_{11} \mathrm{H}_{16} \mathrm{NO}_{6}\right.$ requires 258.0978$)$.

Dilithium 2-(3-Benzylamino-3-oxopropyl)-4-oxoglutarate $1 \mathrm{j}$. ${ }^{1} \mathrm{H}$ NMR $\left(400 \mathrm{MHz}, \mathrm{D}_{2} \mathrm{O}\right) \delta 7.35(5 \mathrm{H}, \mathrm{m}), 4.36(2 \mathrm{H}, \mathrm{s}), 3.03(1 \mathrm{H}$, dd, $J=9.1$ and $17.6 \mathrm{~Hz}), 2.84(1 \mathrm{H}$, dd, $J=5.5$ and $17.8 \mathrm{~Hz}), 2.63$ $(1 \mathrm{H}, \mathrm{m}), 2.29(2 \mathrm{H}, \mathrm{m}), 1.78(2 \mathrm{H}, \mathrm{m}) .{ }^{13} \mathrm{C} \mathrm{NMR}\left(100 \mathrm{MHz}, \mathrm{D}_{2} \mathrm{O}\right) \delta$ $204.3,182.3,175.8,170.0,137.9,128.7,127.4,127.2,43.0,42.3$, $41.7,33.8,28.2$. HRMS (ES-) $m / z 306.0991\left([\mathrm{M}-2 \mathrm{Li}+\mathrm{H}]^{-}\right.$, $\mathrm{C}_{15} \mathrm{H}_{16} \mathrm{NO}_{6}$ requires 306.0978 ).

Dilithium 2-(2,2-Diphenylethylamino-3-oxopropyl)-4-oxoglutarate 1k. ${ }^{1} \mathrm{H}$ NMR $\left(400 \mathrm{MHz}, \mathrm{D}_{2} \mathrm{O}\right) \delta 7.30(10 \mathrm{H}, \mathrm{m}), 4.28(1 \mathrm{H}$, t, $J=8.2 \mathrm{~Hz}), 3.86(2 \mathrm{H}, \mathrm{m}), 2.93(1 \mathrm{H}, \mathrm{dd}, J=8.6$ and $18.7 \mathrm{~Hz})$, $2.71(1 \mathrm{H}$, dd, $J=5.5$ and $18.7 \mathrm{~Hz}), 2.44(1 \mathrm{H}, \mathrm{m}), 2.09(2 \mathrm{H}, \mathrm{t}, J=$ $8.0 \mathrm{~Hz}), 1.54(1 \mathrm{H}, \mathrm{m}), 1.50(1 \mathrm{H}, \mathrm{m}) .{ }^{13} \mathrm{C}$ NMR $\left(100 \mathrm{MHz}, \mathrm{D}_{2} \mathrm{O}\right) \delta$ $205.6,184.3,177.2,171.2,143.6,130.3,129.6,128.4,51.6,45.2$, 44.4, 43.6, 35.5, 30.4. HRMS (ES-) $m / z$ 396.1451 ([M - $2 \mathrm{Li}+$ $\mathrm{H}^{-}, \mathrm{C}_{22} \mathrm{H}_{22} \mathrm{NO}_{6}$ requires 396.1447 ).

General Procedure for the Synthesis of Substituted Glutamic Acids $2 \mathrm{~g}-\mathbf{k}$. To a solution of racemic $1 \mathrm{~g}-\mathbf{k}(0.5 \mathrm{mmol})$ in water $(25 \mathrm{~mL})$ was added cysteine sulfinic acid $(0.5 \mathrm{mmol})$. The $\mathrm{pH}$ of the solution was adjusted to 7.6 with $1 \mathrm{M} \mathrm{NaOH}$ before the addition of $E$. coli AAT (20-100 Units). The reaction was stirred slowly at room temperature and monitored by titration of pyruvate: $5 \mu \mathrm{L}$ aliquots of the reaction mixture were added to $995 \mu \mathrm{L}$ of $0.1 \mathrm{M}$ potassium phosphate buffer, pH 7.6 containing NADH $(0.2 \mathrm{mM})$, and lactate dehydrogenase (1 unit). Pyruvate concentration was calculated from the $\Delta O D$ measured at $340 \mathrm{~nm}$ using $\epsilon \mathrm{NADH}=6220$
$\mathrm{M}^{-1} \cdot \mathrm{cm}^{-1}$. When a conversion rate of $40 \%$ was reached, the reaction mixture was rapidly passed through a column of dowex $50 \mathrm{WX} 8$ resin $\left(\mathrm{H}^{+}\right.$form, $\left.25 \mathrm{~mL}\right)$. The column was then washed with water $(100 \mathrm{~mL})$ until complete elution of CSA and then eluted with $1 \mathrm{M} \mathrm{NH}_{4} \mathrm{OH}$. The ninhydrin positive fractions were combined and concentrated to dryness under reduced pressure. The residue was diluted in water $(5 \mathrm{~mL})$ and, if necessary, the $\mathrm{pH}$ adjusted to 7.0 with $1 \mathrm{M} \mathrm{NaOH}$ before adsorption of the product on a column of dowex $1 \times 8$ resin (200-400 mesh, $\mathrm{AcO}^{-}$form, $1.5 \mathrm{~cm} \times 12$ $\mathrm{cm})$. The column was washed with water $(50 \mathrm{~mL})$ and then eluted with an $\mathrm{AcOH}$ gradient $(0.1-1 \mathrm{M})$ and, in the case of $2 \mathrm{k}$, with $1 \mathrm{M}$ $\mathrm{AcOH}$ in $\mathrm{H}_{2} \mathrm{O}-\mathrm{MeOH}(1: 1, \mathrm{v} / \mathrm{v})$. The ninhydrin positive fractions were combined and concentrated under reduced pressure. The oily residue was dissolved in water $(4 \mathrm{~mL})$, and the solution was lyophilized to afford $2 \mathrm{~g}-\mathbf{k}$ as hygroscopic white solids.

(2S,4R)-4-(3-Amino-3-oxopropyl)glutamic Acid 2g. Yield $35 \mathrm{mg}$, $35 \% ; \mathrm{mp} 120^{\circ} \mathrm{C} ;[\alpha]^{2.5} \mathrm{D}=+34.2(\mathrm{c} 1.0,6 \mathrm{~N} \mathrm{HCl}) .{ }^{1} \mathrm{H}$ NMR $(400$ $\left.\mathrm{MHz}, \mathrm{D}_{2} \mathrm{O}\right) \delta 3.78(1 \mathrm{H}, \mathrm{dd}, J=5.4$ and $8.3 \mathrm{~Hz}), 2.62(1 \mathrm{H}, \mathrm{m})$, $2.34(2 \mathrm{H}, \mathrm{m}), 2.29(1 \mathrm{H}$, ddd, $J=5.5,10.0$ and $15.0 \mathrm{~Hz}), 1.92$ $(3 \mathrm{H}, \mathrm{m}) .{ }^{13} \mathrm{C}$ NMR $\left(100 \mathrm{MHz}, \mathrm{D}_{2} \mathrm{O}\right) \delta 178.7,178.5,173.6,53.0$, 41.6, 32.3, 27.8. HRMS (ES-) $\mathrm{m} / \mathrm{z} 217.0838$ ([M - H] $]^{-}$, $\mathrm{C}_{8} \mathrm{H}_{13} \mathrm{~N}_{2} \mathrm{O}_{5}$ requires 217.0824). Anal. $\left(\mathrm{C}_{8} \mathrm{H}_{14} \mathrm{~N}_{2} \mathrm{O}_{5} \cdot 0.75 \mathrm{H}_{2} \mathrm{O}\right) \mathrm{C}, \mathrm{H}$, $\mathrm{N}$.

(2S,4R)-4-(3-Methylamino-3-oxopropyl)glutamic Acid $2 \mathrm{~h}$. Yield $74 \mathrm{mg}, 46 \% ; \mathrm{mp} 124{ }^{\circ} \mathrm{C} ;[\alpha]^{25} \mathrm{D}=+30.8(\mathrm{c} 1.0,6 \mathrm{~N} \mathrm{HCl}) .{ }^{1} \mathrm{H}$ NMR $\left(400 \mathrm{MHz}, \mathrm{D}_{2} \mathrm{O}\right) \delta 3.75(1 \mathrm{H}$, dd, $J=5.0$ and $8.5 \mathrm{~Hz}), 2.71$ $(3 \mathrm{H}, \mathrm{s}), 2.54(1 \mathrm{H}, \mathrm{m}), 2.29(2 \mathrm{H}, \mathrm{m}), 2.25(1 \mathrm{H}, \mathrm{ddd}, J=5.2,9.7$ and $14.8 \mathrm{~Hz}), 1.89(3 \mathrm{H}, \mathrm{m}) .{ }^{13} \mathrm{C}$ NMR $\left(100 \mathrm{MHz}, \mathrm{D}_{2} \mathrm{O}\right) \delta 179.4$, 176.0, 173.9, 53.1, 42.2, 33.1, 32.5, 28.2, 25.8. HRMS (ES+) $\mathrm{m} / \mathrm{z}$ $255.0961\left([\mathrm{M}+\mathrm{Na}]^{+}, \mathrm{C}_{9} \mathrm{H}_{16} \mathrm{NaN}_{2} \mathrm{O}_{5}\right.$ requires 255.0957). Anal. $\left(\mathrm{C}_{9} \mathrm{H}_{16} \mathrm{~N}_{2} \mathrm{O}_{5}\right) \mathrm{C}, \mathrm{H}, \mathrm{N}$.

(2S,4R)-4-(3-Propylamino-3-oxopropyl)glutamic acid 2i. Yield $94 \mathrm{mg}, 38 \%$; mp $145^{\circ} \mathrm{C} ;[\alpha]^{25}{ }_{\mathrm{D}}=+27.6(c 1.0,6 \mathrm{~N} \mathrm{HCl}) .{ }^{1} \mathrm{H}$ NMR $\left(400 \mathrm{MHz}, \mathrm{D}_{2} \mathrm{O}\right) \delta 3.76(1 \mathrm{H}, \mathrm{dd}, J=5.3$ and $8.4 \mathrm{~Hz}), 3.11$ $(2 \mathrm{H}, \mathrm{t}, J=6.9 \mathrm{~Hz}), 2.57(1 \mathrm{H}, \mathrm{m}), 2.28(2 \mathrm{H}, \mathrm{m}), 2.27(1 \mathrm{H}$, ddd, $J$ $=5.2,9.6$ and $15.0 \mathrm{~Hz}), 1.90(3 \mathrm{H}, \mathrm{m}), 1.48$ (hex, $J=7.3 \mathrm{~Hz}$ ), $0.87(3 \mathrm{H}, \mathrm{t}, J=7.4 \mathrm{~Hz}) .{ }^{13} \mathrm{C}$ NMR $\left(100 \mathrm{MHz}, \mathrm{D}_{2} \mathrm{O}\right) \delta 178.9$, $175.3,173.7,53.1,41.8,41.2,33.2,32.4,28.2,21.7,10.6$. HRMS $(\mathrm{ES}+) \mathrm{m} / \mathrm{z} 283.1277(\mathrm{M}+\mathrm{Na}]^{+}, \mathrm{C}_{11} \mathrm{H}_{20} \mathrm{NaN}_{2} \mathrm{O}_{5}$ requires 283.1270$)$. Anal. $\left(\mathrm{C}_{11} \mathrm{H}_{20} \mathrm{~N}_{2} \mathrm{O}_{5}\right) \mathrm{C}, \mathrm{H}, \mathrm{N}$.

(2S,4R)-4-(3-Benzylamino-3-oxopropyl)glutamic acid 2j. Yield $70 \mathrm{mg}, 39 \%$; mp $110^{\circ} \mathrm{C} ;[\alpha]^{25}=+22.0(c 1.1,6 \mathrm{~N} \mathrm{HCl}) .{ }^{1} \mathrm{H}$ NMR $\left(400 \mathrm{MHz}, \mathrm{D}_{2} \mathrm{O}\right) \delta 7.33(5 \mathrm{H}, \mathrm{m}), 4.33(2 \mathrm{H}, \mathrm{s}), 4.03(1 \mathrm{H}, \mathrm{t}$, $J=7.2 \mathrm{~Hz}), 2.68(1 \mathrm{H}, \mathrm{m}), 2.34(3 \mathrm{H}, \mathrm{m}), 1.96(1 \mathrm{H}, \mathrm{ddd}, J=4.4$, 7.2 and $14.4 \mathrm{~Hz}), 1.92(2 \mathrm{H}, \mathrm{m}) .{ }^{13} \mathrm{C} \mathrm{NMR}\left(100 \mathrm{MHz}, \mathrm{D}_{2} \mathrm{O}\right) \delta 177.8$, $175.1,171.4,137.9,128.8,127.5,127.3,51.4,43.0,40.9,32.8$, $31.6,27.9$. HRMS (ES+) $\mathrm{m} / \mathrm{z} 331.1268\left(\left[\mathrm{M}+\mathrm{Na}^{+}\right.\right.$, $\mathrm{C}_{15} \mathrm{H}_{20} \mathrm{NaN}_{2} \mathrm{O}_{5}$ requires 331.1270$)$; Anal. $\left(\mathrm{C}_{15} \mathrm{H}_{20} \mathrm{~N}_{2} \mathrm{O}_{5} \cdot 0.75 \mathrm{H}_{2} \mathrm{O}\right)$ $\mathrm{C}, \mathrm{H}, \mathrm{N}$.

(2S,4R)-4-(2,2-Diphenylethylamino-3-oxopropyl)glutamic acid 2k. Yield $108 \mathrm{mg}, 37 \%$; mp $135{ }^{\circ} \mathrm{C} ;[\alpha]^{25} \mathrm{D}=+16.9(c 0.9,6 \mathrm{~N}$ $\mathrm{HCl}) .{ }^{1} \mathrm{H}$ NMR $\left(400 \mathrm{MHz}, \mathrm{D}_{2} \mathrm{O}\right) \delta 7.33(8 \mathrm{H}, \mathrm{m}), 7.25(2 \mathrm{H}, \mathrm{m})$, $4.24(1 \mathrm{H}, \mathrm{t}, J=8.3 \mathrm{~Hz}), 3.94(1 \mathrm{H}, \mathrm{t}, J=7.1 \mathrm{~Hz}), 3.82(2 \mathrm{H}, \mathrm{d}, J$ $=8.3 \mathrm{~Hz}), 2.50(1 \mathrm{H}, \mathrm{m}), 2.25(1 \mathrm{H}$, ddd, $J=7.0,9.3$ and $14.8 \mathrm{~Hz})$, $2.12(2 \mathrm{H}, \mathrm{m}), 1.87(1 \mathrm{H}$, ddd, $J=4.4,7.3$ and $14.7 \mathrm{~Hz}), 1.68(2 \mathrm{H}$, m). ${ }^{13} \mathrm{C}$ NMR $\left(100 \mathrm{MHz}, \mathrm{D}_{2} \mathrm{O}\right) \delta 177.8,175.0,171.4,142.1,128.9$, $127.9,127.0,51.3,49.9,43.3,40.7,32.8,31.3,27.9$. HRMS (ES+) $m / z 421.1742\left(\left[\mathrm{M}+\mathrm{Na}^{+}, \mathrm{C}_{22} \mathrm{H}_{26} \mathrm{NaN}_{2} \mathrm{O}_{5}\right.\right.$ requires 421.1739). Anal. $\left(\mathrm{C}_{22} \mathrm{H}_{26} \mathrm{~N}_{2} \mathrm{O}_{5} \cdot 2.75 \mathrm{H}_{2} \mathrm{O}\right) \mathrm{C}, \mathrm{H}, \mathrm{N}$. 
Methyl (2S,4R)-4-(2,2-Diphenylethylamino-3-oxopropyl)pyroglutamate 7. A solution of $2 \mathrm{k}(20 \mathrm{mg}, 0.05 \mathrm{mmol})$ in water ( 5 $\mathrm{mL}$ ) was heated under reflux for $48 \mathrm{~h}$ until complete disappearance of $2 \mathbf{k}$. After evaporation of water under reduced pressure, the solid residue was dried by addition and evaporation of $\mathrm{MeOH}(2 \times 5$ $\mathrm{mL})$. It was then dissolved in $\mathrm{MeOH}(2 \mathrm{~mL})$ and $\mathrm{SOCl}_{2}(25 \mu \mathrm{L}$, $0.35 \mathrm{mmol}$ ) was added. The mixture was stirred at room temperature for $18 \mathrm{~h}$ before concentration under reduced pressure. Flash chromatography (eluent, AcOEt/acetone, 8:2, v/v) afforded 7 (11 $\mathrm{mg}, 56 \%)$ isolated as a colorless viscous liquid: $[\alpha]^{25}{ }_{\mathrm{D}}=+20.8(\mathrm{c}$ $\left.0.6, \mathrm{CHCl}_{3}\right) .{ }^{1} \mathrm{H}$ NMR $\left(400 \mathrm{MHz}, \mathrm{C}_{6} \mathrm{D}_{6}\right) \delta 7.14(8 \mathrm{H}, \mathrm{m}), 7.02(2 \mathrm{H}$, m), $5.98(1 \mathrm{H}, \mathrm{s}$, broad), $5.65(1 \mathrm{H}, \mathrm{t}, J=5.5 \mathrm{~Hz}) ; 4.18(1 \mathrm{H}, \mathrm{t}, J=$ $8.0 \mathrm{~Hz}), 3.93(1 \mathrm{H}$, ddd, $J=6.3,7.9$ and $13.8 \mathrm{~Hz}), 3.77(1 \mathrm{H}$, ddd, $J=5.6,7.8$ and $13.5 \mathrm{~Hz}), 3.39(1 \mathrm{H}, \mathrm{dd}, J=3.5$ and $9.0 \mathrm{~Hz}), 3.22$ $(3 \mathrm{H}, \mathrm{s}), 2.09-1.93(3 \mathrm{H}, \mathrm{m}) ; 1.85$ (1H, ddd, $J=3.5,8.8$ and 12.8 $\mathrm{Hz}), 1.69(2 \mathrm{H}, \mathrm{m}), 1.43(1 \mathrm{H}, \mathrm{td}, J=8.7$ and $13.0 \mathrm{~Hz}) .{ }^{13} \mathrm{C}$ NMR $\left(100 \mathrm{MHz}, \mathrm{D}_{2} \mathrm{O}\right) \delta 178.9,172.5,171.7,142.8,128.9,128.6,126.8$. $53.4,51.7,51.2,44.2,38.1,33.8,31.7,27.7$. HRMS (ES+) $\mathrm{m} / \mathrm{z}$ $395.1976\left([\mathrm{M}+\mathrm{H}]^{+}, \mathrm{C}_{23} \mathrm{H}_{27} \mathrm{~N}_{2} \mathrm{O}_{4}\right.$ requires 395.1971$)$.

\section{Modeling}

In Silico Study of 4-Substituted Glu Analogues and Selected Ligands. The modeling study was performed using the software package MOE (Molecular Operating Environment, v2006.08, Chemical Computing Group, 2006) using the builtin $\mathrm{mmff} 94 \mathrm{x}$ forcefield and the GB/SA continuum solvent model. General procedure for compounds $\mathbf{2 g}-\mathbf{k}$ : The $\gamma$-carboxylate group was protonated and the compound submitted to a stochastic conformational search (standard setup). Conformations which hold intramolecular hydrogen bond(s) or $\pi$-cation interactions were discarded. Superimpositions of selected conformations were carried out using the built-in function in MOE by fitting the ammonium group and the two carboxylate groups.

\section{Pharmacology}

FLIPR Membrane Potential (FMP) Assay. The construction of Human Embryonic Kidney 293 (HEK293) cell lines stably expressing human EAAT1, EAAT2, and EAAT3 have been reported previously, and the pharmacological characterization of $\mathbf{2 a - k}$ (2d is exempt) at the cell lines in the FMP assay was performed essentially as described. ${ }^{12}$ Briefly, cells were split into poly-D-lysine (PDL)-coated black 96-well plates with a clear bottom (BD Biosciences, Palo Alto, CA) in Dulbecco's modified Eagle medium supplemented with penicillin (100 $\mathrm{U} / \mathrm{mL})$, streptomycin $(100 \mu \mathrm{g} / \mathrm{mL}), 10 \%$ dialyzed fetal bovine serum, and $1 \mathrm{mg} / \mathrm{mL} \mathrm{G}-418$ (culture medium). At 16-24 h later, the medium was aspirated and the cells were washed with 100 $\mu$ L Krebs buffer $\left[140 \mathrm{mM} \mathrm{NaCl} / 4.7 \mathrm{mM} \mathrm{KCl} / 2.5 \mathrm{mM} \mathrm{CaCl}_{2} /\right.$ $1.2 \mathrm{mM} \mathrm{MgCl} / 11 \mathrm{mM}$ HEPES/10 mM D-glucose, pH 7.4]. Then $50 \mu \mathrm{L}$ of Krebs buffer was added to each well (in the characterization of nonsubstrate inhibitors, the inhibitors were added to this buffer). Then $50 \mu \mathrm{L}$ of Krebs buffer supplemented with FMP assay dye was then added to each well (in the experiments with the nonsubstrate inhibitors, the compounds were added to this solution), and the plate was incubated at 37 ${ }^{\circ} \mathrm{C}$ for $30 \mathrm{~min}$. The plate was assayed at $30^{\circ} \mathrm{C}$ in a NOVOstar plate reader measuring emission at $560 \mathrm{~nm}$ caused by excitation at $530 \mathrm{~nm}$ before and up to $1 \mathrm{~min}$ after addition of $33 \mu \mathrm{L}$ of substrate solution. The experiments were performed in duplicate at least three times for each compound. For the characterization of nonsubstrate inhibitors, $30 \mu \mathrm{M}$ Glu was used as substrate concentration at the EAAT1- and EAAT3-cell lines, whereas $50 \mu \mathrm{M}$ Glu was used as substrate concentration at the EAAT2cell line.

$\left[{ }^{3} \mathbf{H}\right]$-D-Asp Uptake Assay. The EAAT1-, EAAT2-, and EAAT3-HEK293 cell lines were characterized pharmacologi- cally in a $\left[{ }^{3} \mathrm{H}\right]$-D-Asp assay essentially as previously described. ${ }^{12}$ Briefly, cells were split into PDL-coated white 96-well plates (Perkin-Elmer, Boston, MA) in culture medium. At 16-24 h later, the medium was aspirated, and cells were washed 3 times with $100 \mu \mathrm{L}$ of assay buffer (Hanks Buffered Saline Solution supplemented with $1 \mathrm{mM} \mathrm{CaCl} 2$ and $1 \mathrm{mM} \mathrm{MgCl}$ ). Then 50 $\mu \mathrm{L}$ of assay buffer supplemented with $30 \mathrm{nM}\left[{ }^{3} \mathrm{H}\right]$-D-Asp and various concentrations of different ligands was added to each well, and the plate was incubated at $37^{\circ} \mathrm{C}$ for $7 \mathrm{~min}$. The wells were then washed with $3 \times 100 \mu \mathrm{L}$ of ice-cold assay buffer, and $150 \mu \mathrm{L}$ of Microscint20 scintillation fluid (Perkin-Elmer) was added to each well. The plate was shaken for $1 \mathrm{~h}$ and counted in a TopCounter (Perkin-Elmer). Nonspecific [ $\left.{ }^{3} \mathrm{H}\right]-\mathrm{D}-$ Asp transport in the cell lines was determined using $3 \mathrm{mM}$ Glu.

AMPA, KA and NMDA Binding Assays. Glu analogues were evaluated for AMPA, KA, NMDA (CGP 39653) binding affinity in native rat synaptosomes, in accordance with previously described experimental procedure. ${ }^{22}$

iGluR5-7 Binding Assay. Rat iGluR5 $(Q)_{1 \mathrm{~b}}$, iGluR6$(V, C, R)$ a, and iGluR7a were inserted into recombinant baculoviruses, receptors expressed by infection of $S f 9$ insect cells and infected $S f 9$ cell membranes utilized for radioligand binding assays. Cells were maintained in BaculoGold Max-XP serumfree medium (BD Biosciences-Pharmingen, San Diego, CA) according to standard protocols in "Guide to Baculovirus Expression Vector Systems and Insect Cell Culture Techniques" (Life Technologies, Paisley, UK) and "Baculovirus Expression Vector System: Procedures and Methods Manual", 2nd ed., (Pharmingen). [ $\left.{ }^{3} \mathrm{H}\right]$-SYM2081 $\left(\left[{ }^{3} \mathrm{H}\right]-(2 \mathrm{~S}, 4 R)\right.$-4-methylglutamic acid) $(47.9 \mathrm{Ci} / \mathrm{mmol}$; ARC Inc., St. Louis, MO) microtiter plate binding assays were performed in $250 \mu \mathrm{L}$ of assay buffer ( 50 $\mathrm{mM}$ Tris- $\mathrm{HCl}, \mathrm{pH} 7.1$ at $4{ }^{\circ} \mathrm{C}$ ) at a protein concentration from 10 to $50 \mu \mathrm{g} / \mathrm{mL}$, incubating for $1-2 \mathrm{~h}$ at $4{ }^{\circ} \mathrm{C}$. Bound and free radiolabel were separated by cold filtration through GF/B glass fiber filters (UniFilter-96, Perkin-Elmer) on a Perkin-Elmer FilterMate manifold using two washes with cold assay buffer. Nonspecific binding was determined in the presence of $1 \mathrm{mM}$ Glu. Competition studies were performed using 1-5 $\mathrm{nM}$ radiolabel in the presence of $10 \mathrm{nM}$ to $1 \mathrm{mM}$ cold ligand. Filters were dried $1 \mathrm{~h}$ at $50^{\circ} \mathrm{C}$ and then $50 \mu \mathrm{L} /$ well of Microscint 20 was added. Radioactivity was detected as DPM using a TopCounter. The affinity of the radiolabel for the kainate receptors was determined from saturation binding experiments, $K_{\mathrm{d}}$ (mean \pm SEM): $\operatorname{iGluR5}(Q)_{\mathrm{lb}}, 0.663 \pm 0.035 \mathrm{nM}$; iGluR6 $(V, C, R)$ a, $17.0 \pm 3.0 \mathrm{nM}$; iGluR7a, $5.69 \pm 1.12 \mathrm{nM}$. Competition data were analyzed using Grafit v3.00 (Erithacus Software Ltd., Horley, UK) and fit to equations as previously described for the determination of $\mathrm{K}_{\mathrm{i} \cdot}{ }^{23}$

mGluR Assays. Binding and functional assays were carried out as described in ref 9.

Acknowledgment. We thank the The Carlsberg Foundation, Lundbeck Foundation, The Danish Medical Research Council, the French National Center for Scientific Research (CNRS), and the Novo Nordisk Foundation for funding. We are grateful to Prof. Kagamiyama's group (Osaka Medical College) for providing us with the AAT overexpressing E. coli strains. Dr. Susan Amara is thanked for providing us with the EAAT cDNAs.

Supporting Information Available: Combustion analysis data of compounds $2 \mathrm{~g}-\mathbf{k}$ and $5 \mathrm{~g}-\mathrm{k}$, and ${ }^{1} \mathrm{H}$ and ${ }^{13} \mathrm{C}$ NMR spectra of compounds $\mathbf{2} \mathbf{g}-\mathbf{k}$. HPLC analyses of compound $\mathbf{2 k}$. This material is available free of charge via the Internet at http://pubs.acs.org. 


\section{References}

(1) Campiani, G.; Fattorusso, C.; De Angelis, M.; Catalanotti, B.; Butini, S.; Fattorusso, R.; Fiorini, I.; Nacci, V.; Novellino, E. Neuronal highaffinity sodium-dependent glutamate transporters (EAATs): targets for the development of novel therapeutics against neurodegenerative diseases. Curr. Pharm. Des. 2003, 9, 599-625.

(2) Seal, R. P.; Amara, S. G. Excitatory amino acid transporters: a family in flux. Annu. Rev. Pharmacol. Toxicol. 1999, 39, 431-456.

(3) Bräuner-Osborne, H.; Egebjerg, J.; Nielsen, E. O.; Madsen, U.; Krogsgaard-Larsen, P. Ligands for glutamate receptors: design and therapeutic prospects. J. Med. Chem. 2000, 43, 2609-2645.

(4) Meldrum, B. S. Glutamate as a neurotransmitter in the brain: review of physiology and pathology. J. Nutr. 2000, 130, 1007S-1015S

(5) Bunch, L.; Nielsen, B.; Jensen, A. A.; Brauner-Osborne, H. Rational design and enantioselective synthesis of $(1 R, 4 S, 5 R, 6 S)-3$ azabicyclo[3.3.0]octane-4,6-dicarboxylic acid: a novel inhibitor at human glutamate transporter subtypes 1,2, and 3.J. Med. Chem. 2006, 49, $172-178$.

(6) Alaux, S.: Kusk, M.; Sagot, E.; Bolte, J.; Jensen, A. A.; BraunerOsborne, H.; Gefflaut, T.; Bunch, L. Chemoenzymatic synthesis of a series of 4-substituted glutamate analogues and pharmacological characterization at human glutamate transporters subtypes 1-3.J. Med. Chem. 2005, 48, 7980-7992.

(7) Bräuner-Osborne, H.; Bunch, L.; Chopin, N.; Couty, F.; Evano, G.; Jensen, A. A.; Kusk, M.; Nielsen, B.; Rabasso, N. Azetidinic Amino Acids: Stereocontrolled Synthesis and Pharmacological Characterization as Ligands for Glutamate Receptors and Transporters. Org. Biomol. Chem. 2005, 3, 3926-3936.

(8) Faure, S.; Jensen, A. A.; Maurat, V.; Gu, X.; Sagot, E.; Aitken, D. J.; Bolte, J.; Gefflaut, T.; Bunch, L. Stereoselective chemoenzymatic synthesis of the four stereoisomers of L-2-(2-carboxycyclobutyl)glycine and pharmacological characterization at human excitatory amino acid transporter subtypes 1, 2, and 3.J. Med. Chem. 2006, 49, 6532-6538.

(9) Sagot, E.; Pickering, D. S.; Pu, X.; Umberti, M.; Stensbøl, T. B.; Nielsen, B.; Chapelet, M.; Bolte, J.; Gefflaut, T.; Bunch, L. ChemoEnzymatic Synthesis of a Series of 2,4-Syn-Functionalized $(S)$ Glutamate Analogues: New Insight into the Structure-Activity Relation of Ionotropic Glutamate Receptor Subtypes 5, 6 and 7. J. Med Chem 2008, 51, 4093-4103.

(10) Chakrabortty, P. N. D., R.; Dasgupta, S. K.; Ghosh, S. R.; Ghatak, U. R. New synthetic routes to tetracyclic bridged-bicyclo[3.2.1] octane intermediates by intramolecular alkylation reactions through [alpha] diazomethyl ketones of hydroaromatic [gamma].[delta]-unsaturated acids. Tetrahedron 1972, 28, 4653-4665.

(11) Echalier, F.; Constant, O.; Bolte, J. Enzymatic-Synthesis of 4-MethylL-Glutamic and 4-Ethyl-L-Glutamic Acids. J. Org. Chem. 1993, 58 , 2747-2750.

(12) Jensen, A. A.; Bräuner-Osborne, H. Pharmacological characterization of human excitatory amino acid transporters EAAT1, EAAT2, and EAAT3 in a fluorescence-based membrane potential assay. Biochem. Pharmacol. 2004, 67, 2115-2127.
(13) Shimamoto, K.; LeBrun, B.; Yasuda-Kamatani, Y.; Sakaitani, M.; Shigeri, Y.; Yumoto, N.; Nakajima, T. DL-threo-beta-benzyloxyaspartate, a potent blocker of excitatory amino acid transporters. Mol. Pharmacol. 1998, 53, 195-201.

(14) Campiani, G.; De Angelis, M.; Armaroli, S.; Fattorusso, C.; Catalanotti, B.; Ramunno, A.; Nacci, V.; Novellino, E.; Grewer, C.; Ionescu, D.; Rauen, T.; Griffiths, R.; Sinclair, C.; Fumagalli, E.; Mennini, T. A rational approach to the design of selective substrates and potent nontransportable inhibitors of the excitatory amino acid transporter EAAC1 (EAAT3). New glutamate and aspartate analogues as potential neuroprotective agents. J. Med. Chem. 2001, 44, 2507-2510.

(15) Mennini, T.; Fumagalli, E.; Gobbi, M.; Fattorusso, C.; Catalanotti, B.; Campiani, G. Substrate inhibitors and blockers of excitatory amino acid transporters in the treatment of neurodegeneration: critical considerations. Eur. J. Pharmacol. 2003, 479, 291-296.

(16) Koch, H. P.; Kavanaugh, M. P.; Esslinger, C. S.; Zerangue, N.; Humphrey, J. M.; Amara, S. G.; Chamberlin, A. R.; Bridges, R. J. Differentiation of substrate and nonsubstrate inhibitors of the highaffinity, sodium-dependent glutamate transporters. Mol. Pharmacol. 1999, 56, 1095-1104.

(17) Hogner, A.; Kastrup, J. S; Jin, R. Liljefors, T; Mayer, M. L. Egebjerg, J.; Larsen, I. K.; Gouaux, E. Structural basis for AMPA receptor activation and ligand selectivity: Crystal structures of five agonist complexes with the GluR2 ligand-binding core. J. Mol. Biol. 2002, 322, 93-109.

(18) Bunch, L.; Liljefors, T.; Greenwood, J. R.; Frydenvang, K.; BraunerOsborne, H.; Krogsgaard-Larsen, P.; Madsen, U. Rational design, synthesis, and pharmacological evaluation of 2-azanorbornane-3-exo,5endo-dicarboxylic acid: A novel conformationally restricted glutamic acid analogue. J. Org. Chem. 2002, 68, 1489-1495.

(19) Emiliozzi, R.; Pichat, L. A simple method for the preparation of cysteinesulfinic acid. Bull. Soc. Chim. Fr. 1959, 1887-1888.

(20) Kamitori, S.; Hirotsu, K.; Higuchi, T.; Kondo, K.; Inoue, K. Kuramitsu, S.; Kagamiyama, H.; Higuchi, Y.; Yasuoka, N.; Kusunoki, M.; Matsuura, Y. Overproduction and Preliminary X-Ray Characterization of Aspartate-Aminotransferase from Escherichia coli. J. Biochem. 1987, 101, 813-816.

(21) Augustine, R. L.; Bellina, R. F.; Gustavsen, A. J. Hydrogenation of beta-Amino-alpha,beta-Unsaturated Esters. J. Org. Chem. 1968, 33 , 1287-1288.

(22) Hermit, M. B.; Greenwood, J. R.; Nielsen, B.; Bunch, L.; Jorgensen, C. G.; Vestergaard, H. T.; Stensbol, T. B.; Sanchez, C.; KrogsgaardLarsen, P.; Madsen, U.; Bräuner-Osborne, H. Ibotenic acid and thioibotenic acid: a remarkable difference in activity at group III metabotropic glutamate receptors. Eur. J. Pharmacol. 2004, 486, 241250 .

(23) Nielsen, B. S.; Banke, T. G.; Schousboe, A.; Pickering, D. S. Pharmacological properties of homomeric and heteromeric GluR1(o) and GluR3(o) receptors. Eur. J. Pharmacol. 1998, 360, 227-238.

JM800091E 